\title{
PERANAN KEPEMIMPINAN TRANSFORMASI GEMBALA SIDANG BAGI PERTUMBUHAN GEREJA MASA KINI
}

\section{Innawati}

\section{PENDAHULUAN}

Blackaby mengatakan bahwa kepemimpinan rohani adalah sebuah panggilan yang terurapi yang menjadi teladan dan harapan dunia dalam menghadirkan Injil dalam apapun latar belakang profesinya. Barna dalam Sendjaya menyimpulkan hasil penelitiannya selama lima belas tahun tentang kehidupan gereja secara global, dan konklusinya bahwa gereja telah kehilangan pengaruhnya karena ketiadaan kepemimpinan yang efektif dan cacat karakter. ${ }^{1}$ Gereja mengalami tantangan yang besar dari segi sumber daya manusianya dan organisasinya serta degradasi kuantitas dan kualitas. Kepemimpinan adalah pengaruh yang dipancarkan keluar dari dalam diri seorang pemimpin. Akar masalahnya adalah yang berada di dalam diri bukan yang berada di luar. Yang di luar adalah sebab dari akibat yang ditimbulkan. Dalam artikel ini penulis memfokuskan pada karakter pemimpin transformatif, yang mengubah dari dalam dirinya yang akan berdampak ke kepemimpinannya kemudian. $^{2}$

Dari latar belakang masalah dapat diidentifikasi beberapa kebutuhan mendesak bagi kehidupan gereja masa kini, antara lain kurangnya pengaruh, kurangnya orang-orang Kristen yang bekerja di dunia sekuler untuk melayani pekerjaan Tuhan, penurunan jemaat gereja dalam kuantitas dan kualitas, kurangnya pemimpin rohani yang berkualitas untuk menjawab kebutuhan dunia yang lapar dan haus akan kehidupan yang damai sejahtera, dan kurangnya peranan kepemimpinan transformasi Gembala Sidang, yaitu jemaat beriman, bagi pertumbuhan gereja masa kini.

Sesuai dengan latar belakang masalah kajian ini bertujuan menjawab persoalan konsep kepemimpinan transformasi dan peran dari gembala sidang dalam pertumbuhan gereja masa kini. Adapun kajian ini bermanfaat memberikan masukan kepada para Gembala Sidang untuk meningkatkan kepemimpinannya dengan mengimplementasikan prinsip kepemimpinan transformasi dalam perannya sebagai Gembala Sidang, yang akan berdampak positif bagi pertumbuhan gereja mereka.

\footnotetext{
${ }^{1}$ Sendjaya, Kepemimpinan Kristen, (Yogyakarta: Penerbit Kairos, 2004), 17

${ }^{2}$ Peter Scazzero \& Warren Bird, Gereja yang Sehat secara Emosional, (Batam: Gospell Press, 2005), 52
} 


\section{BAB I}

\section{KEPEMIMPINAN TRANSFORMATIF}

Secara umum kepemimpinan merupakan salah satu fungsi manajemen yang memegang peran yang amat penting dalam organisasi. Di dalam kepemimpinan tercakup tiga faktor utama: kekuasaan, wewenang, dan pengaruh. Wills mendefinisikan kepemimpinan sebagai mengarahkan orang lain menuju tujuan yang diperjuangkan bersama oleh pemimpin dan pengikut-pengikutnya. ${ }^{3}$ Packard, Bennis, Nanus, dan Yudho berpendapat bahwa kepemimpinan adalah proses membuat orang lain ingin melakukan sesuatu yang aku yakini harus dilakukan dan benar. ${ }^{4}$

Tomatala menuliskan bahwa kepemimpinan Kristen adalah suatu proses terencana yang dinamis dalam konteks pelayanan Kristen (yang menyangkut faktor waktu, tempat dan situasi khusus) yang di dalamnya oleh campur tangan Allah, Ia memanggil bagi diri-Nya seorang pemimpin (dengan kapasitas penuh) untuk memimpin umat-Nya guna mencapai tujuan Allah (yang membawa keuntungan bagi pemimpin, bawahan, dan lingkungan hidup) bagi dan melalui umat-Nya untuk kejayaan Kerajaan-Nya. ${ }^{5}$ Bowling mengatakan kepemimpinan rohani yang bersifat pribadi bukan karena wilayah pengaruhnya, tetapi karena sumber dan potensi kekuatan pengaruh yang dimilikinya berasal dari Tuhan Yesus Kristus dan diarahkan kepada Yesus Kristus. ${ }^{6}$ Kepemimpinan dalam Gereja adalah salah satu bentuk kepemimpinan rohani. Dengan demikian, kepemimpinan Kristen dapat disimpulkan sebagai konsep pencapaian tujuan bersama dalam suatu organisasi, yang dijiwai semangat Kristiani. Hubungan antara pemimpin dan anak buah merupakan persekutuan (hubungan personal) yang didasari oleh kasih.

Seorang Pemimpin Kristen adalah orang yang telah dipilih Allah untuk memimpin umat-Nya memperluas kerajaan Allah. Ada tiga ciri yang membedakan seorang Pemimpin dari seorang pengikut yaitu seorang pemimpin Kristen dipanggil Tuhan, orang dengan karakter seperti Kristus ${ }^{7}$, dan memiliki kemampuan fungsional yang memungkinkan dia melakukan berbagai tugas dan membimbing orang-orang menuju kesempurnaan tujuan sebagai hamba Allah. ${ }^{8}$ Dasar etika moral kepemimpinan Kristen dilandaskan atas "inkarnasi Yesus Kristus”. Perwujudan etika moral kepemimpinan Kristen harus dinyatakan dalam sikap kehidupannya.

Sehubungan dengan penjelasan di atas maka dapat disimpulkan bahwa ada tiga hal utama yang harus diperhatikan dalam kehidupan seorang pemimpin yaitu Identity, Integrity dan Intimacy.

\footnotetext{
${ }^{3}$ George Barna, Leaders on Leadership, (Malang: Gandum Mas, 2002), 23

4 Bambang Yudho, How to Become A Christian Leader. Prinsip-Prinsip Kepemimpinan Kristen, (Yogyakarta: Penerbit Andi, 2006), 6

${ }^{5}$ Yakob Tomatala, Kepemimpinan yang Dinamis, (Malang: Gandum Mas, 1997), 43-44

${ }^{6}$ Bowling, Kepemimpinan Penuh Kasih Karunia, (Jakarta: Metanoia, 2001), 4

${ }^{7}$ George Barna, Leaders, 26-27

${ }^{8}$ Isak Suria, Pembentukan Karakter Pemimpin Kristen (Spirituality Formation),(Malang: GTI Bukit Zaitun, 2007), 7
} 


\section{IDENTITY}

Pertama adalah Identitas Diri (Citra Diri). Gambar diri (citra diri) yang baik bisa diartikan merasa senang kepada diri sendiri, orang lain, dan kehidupan. ${ }^{9}$ Kita menciptakan dunia kita dengan apa yang kita percayai tentang diri kita. Kepercayaan adalah produk dari pikiran, pikiran menciptakan kepercayaan, kepercayaan menciptakan keyakinan, keyakinan menciptakan sikap, sikap mengendalikan persepsi, dan persepsi mendiktekan perilaku. Jadi, penting bagi seorang pemimpin untuk mengidentifikasikan (mencitrakan) dirinya, karena kehidupan kita adalah apa yang kita pikir. ${ }^{10}$

Seorang pemimpin yang mengenali dirinya dengan baik; mengenali kelebihan dan kekurangannya serta menyadari jati dirinya di dalam Kristus akan memiliki rasa aman. Rasa aman inilah yang akan mendukung kepemimpinannya di dalam pelayanannya.

\section{INTEGRITY}

Kedua adalah Integritas Diri. Integritas berasal dari bahasa Latin "integrare" yang artinya "menjadi utuh" dan diadopsi ke dalam bahasa Inggris sebagai "integrity". Jadi, integritas adalah tentang sesuatu kesatuan yang utuh. Pemimpin dengan integritas adalah seorang yang memunyai kepribadian utuh dalam kata dan perbuatan ${ }^{11}$. Integritas adalah konsistensi dalam perkataan dan tindakan seseorang; kelayakan untuk dipercaya; karakter yang benar. ${ }^{12}$ Sudomo dan Yukl dalam Innawati Teddywono mengatakan bahwa seorang pendeta, penulis dan pembicara bernama David Jeremiah berkata,'Integritas adalah menjaga komitmenku sekalipun situasi ketika aku membuat komitmen tersebut telah berubah". ${ }^{13}$ Seorang pemimpin yang mengharapkan dapat mengilhami orang lain untuk mendukung ideologi atau visi harus menjadi contoh dalam perilakunya sendiri. Integritas juga berarti mengambil tanggungjawab terhadap tindakan dan keputusannya. Seorang pemimpin yang membuat keputusan atas suatu masalah dan kemudian mencoba menolak tanggungjawab bila keputusan tersebut gagal atau menjadi kontroversial, akan memberi label tidak dapat dipercaya" pada dirinya sendiri.

Orang yang memiliki integritas, memunyai sifat jujur, bertanggungjawab, transparan, setia, konsisten dan dapat dipercaya. Kata dan perbuatannya selaras. Pribadi yang utuh. Untuk menjadi pemimpin, seseorang harus memunyai pengikut. Dan untuk memunyai pengikut, seseorang harus dipercaya. Jadi, kualitas tertinggi seorang pemimpin jelas adalah integritas. Tanpa integritas, tak mungkin diraih sukses sejati, itu terjadi di segala bidang kehidupan. Beberapa ayat di Alkitab mengenai integritas: Yakobus 1:8; Amsal 10:9; 11:3; 11:6; $21: 8$.

\footnotetext{
${ }^{9}$ Myles Munroe, The Spirit of Leadership, (Jakarta: Penerbit Immanuel, 2006), 276

${ }^{10}$ Ibid, 15

${ }^{11}$ Yudho, How to Become..., 10

${ }^{12}$ Myles Munroe. The Spirit of Leadership, (Jakarta: Penerbit Immanuel, 2006), 275-277

${ }^{13}$ Innawati Teddywono, Tesis: "Pengaruh Kepemimpinan Kristen BerbasisKewirausahaan dan Pemberdayaan Jemaat Terhadap Pertumbuhan Gereja. Studi Kasus Di Gereja Pantekosta Pusat Surabaya Elim Malang, (Malang, 2010), 68
} 
Salah satu kunci sukses seorang pemimpin adalah memiliki integritas. Dengan memiliki integritas, seorang pemimpin akan dihargai dan disegani oleh orang-orang yang dipimpinnya. Dalam dunia kerja dan pelayanan yang penuh tantangan, figur pemimpin yang bisa bertahan dalam situasi sulit sangat dibutuhkan. Ada satu kualitas yang mutlak dimiliki oleh seorang pemimpin, yaitu integritas. Integritas menjadi dasar dari kesuksesan.

Integritas akan mengantarkan seorang pemimpin lebih jauh daripada kualitas lain yang manapun, integritas itu adalah lebih daripada perkataan kita. Orang bisa melupakan perkataan-perkataan seorang pemimpin, tapi ia tidak akan melupakan bagaimana sang pemimpin menjalani kehidupannya. Sulit bagi seorang pemimpin untuk mencapai puncak organisasi bila ia mengompromikan integritasnya dengan mengkhianati suatu kepercayaan. Kalau kita mau berprestasi dan berbuat banyak sebagai pemimpin, janganlah pernah mengkompromikan integritas kita. Seorang yang tidak memiliki integritas tidaklah memenuhi syarat untuk menuntun orang lain mencapai karakter yang lebih tinggi.

\section{INTIMACY}

Ketiga adalah Intimacy, adalah kemampuan seorang pemimpin untuk bisa memupuk dan mengembangkan hubungannya dengan Tuhan dan sesamanya dengan baik.

Seorang pemimpin rohani seyogyanya terlebih dahulu memiliki kedekatan pribadi dengan Tuhan. Kesadaran akan siapa dirinya di hadapan Tuhan, kesadaran akan ketidakberdayaan dirinya tanpa Tuhan adalah merupakan titik awal kesadaran akan kebergantungannya kepada Tuhan. Ratapan 3:22-24 menunjukkan bahwa hidup manusia, dan manusia hidup hanya bergantung dari kemurahan Tuhan semata-mata. Seorang pemimpin kristiani yang secara pribadi intim dengan Tuhan, akan mengutamakan Kristus di dalam hidupnya. Ia hidup berfokus pada Kristus, ia hidup bagi Kristus (Flp. 1:21) ${ }^{14}$ dan menjadi pelaku Firman Tuhan ${ }^{15}$.

Seorang pemimpin rohani yang intim dengan Tuhan, akan menerima dan mengasihi sesamanya dan dirinya sendiri, selanjutnya ia pun akan dapat menjalin, memupuk dan mengembangkan hubungannya dengan sesamanya dengan harmonis.

Ketiga hal tersebut di atas: Identity, Integrity dan Intimacy memiliki keterkaitan; seorang pemimpin kristiani yang menyadari identitasnya di dalam Kristus, akan menjaga integritas dirinya serta memiliki intimasi dengan Tuhan dan sesamanya.

${ }^{14}$ Filipi 1:21 karena bagiku hidup adalah Kristus dan mati adalah keuntungan.

15 Yakobus 1:25 tetapi barangsiapa meneliti hukum yang sempurna, yaitu hukum yang memerdekakan orang, dan ia bertekun di dalamnya, jadi bukan hanya mendengar untuk melupakannya, tetapi sungguh-sungguh melakukannya, ia akan berbahagia oleh perbuatannya. 


\section{BAB II}

\section{CHARACTER, COMPETENCY, CONVICTION, COMMITMENT}

Seorang pemimpin transformatif kristiani harus memiliki empat aspek dalam dirinya yaitu: karakter (character), kompetensi (competency), pendirian (conviction), dan komitmen (commitment). ${ }^{16}$

Aspek pertama adalah Character. Karakter adalah yang menjadi penunjang dari arah kepemimpinan seseorang seperti tertera dalam Alkitab yang memberikan suatu kualifikasi kepemimpinan (I Tim. 3:1-7; Tit. 1:5-9). Karakter adalah elemen terpenting dari kepemimpinan, ini berlaku baik di dunia kepemimpinan sekuler, terlebih lagi di dunia kepemimpinan rohani. Karakter bicara tentang kekudusan (I Pet. 1:14-19), kerendahan hati (Mat. 7:1-5) dan kebiasaan menjadikan hidup kudus dan rendah hati menjadi gaya hidupnya. Kebiasaan atau gaya hidup ini harus diupayakan terus menerus, menunjuk pada ayat Alkitab I Korintus 9:24-27. Kartono menulis bahwa karakter adalah bentuk organisasi dari kehidupan perasaan, pengenalan dan kehendak yang diarahkan pada sistem nilai, dan diekspresikan dengan relatif konsekuen pada pencapaian nilai-nilai yang ingin dicapai. ${ }^{17}$

Berdasarkan penjelasan di atas, maka penulis menyimpulkan bahwa karakter seorang pemimpin adalah jiwa dari kepemimpinan. Kepemimpinan tanpa seorang pemimpin yang berkarakter, tak akan berhasil. Karakter seorang pemimpinlah yang menggerakkan kepemimpinannya. Karakter seorang pemimpin yang baik mendahului kesuksesan kepemimpinannya.

Aspek kedua yang sangat menunjang berhasilnya suatu kepemimpinan adalah kecakapan atau Competency dari seorang pemimpin. Menurut Maxwell, kompetensi adalah kemampuan seorang pemimpin untuk mengatakannya, merencanakannya, dan melakukannya dengan sedemikian rupa sehingga orang lain mengetahui bahwa ia mengetahui caranya, dan mengetahui bahwa mereka ingin menjadi pengikutnya. ${ }^{18}$ Beberapa kompetensi dibutuhkan bagi keberhasilan seorang Pemimpin transformatif kristiani, seperti kreatif dan inovatif, keberanian menghadapi resiko, bekerja keras, inisiatif, bertanggungjawab, mandiri, bersikap dan berpikir optimistis, pembelajar seumur hidup, ulet, tekun, kemampuan analitik, sikap yang antisipatif \& proaktif, disiplin, kemampuan menentukan prioritas. Namun yang terpenting dari semua kompetensi ini adalah kemampuan berkomunikasi. Komunikasi adalah kemampuan seseorang berbagi ide, berbagi kehidupan dengan orang lain.

Penulis menyimpulkan bahwa kompetensi adalah kemampuan diri seseorang yang merupakan kristalisasi dari pengalaman hidupnya, yang akan menyertainya dan makin bertambah dari waktu ke waktu. Kompetensi yang diperlukan seorang pemimpin Kristen adalah bisa membimbing orang lain menemukan jawaban, bisa memberikan pertimbangan yang penting terhadap suatu masalah yang dihadapi.

\footnotetext{
${ }^{16}$ David Handojo, Personal Leadership, (Malang: t.p, 2010), 5-7.

${ }^{17}$ Kartini Kartono, Teori Kepribadian, (Bandung: Penerbit Alumni, 1980), 50

18 John C. Maxwell, The 21 Indispensable Qualities of a Leader, (Bandung: Interaksara, t.t),
} 
Aspek ketiga adalah Conviction. Bagian ini menjelaskan bagaimana pengertian seorang calon Pemimpin terhadap kebenaran Alkitab, makna Salib dan kebangkitan Yesus. Seorang pemimpin harus mampu menjaga agar arah kepemimpinannya tetap fokus pada kepentingan pekerjaan Tuhan, bukan pada ambisi pribadinya. Refleksi dirinya terhadap visinya harus tetap dijaga agar tidak keluar dari jalurnya. Penyerahan dirinya yang kuat kepada Tuhan dilatih melalui kehidupan doa dan Firman yang merupakan alat pengontrol yang kuat dalam pengendalian ambisi pribadinya.

Conviction adalah cermin dari kedalaman pemahaman seorang pemimpin rohani dalam memaknai salib Kristus secara pribadi yang tercermin pada sikap hidupnya yang teguh bersandar pada Tuhan. Beriman kepada Kristus.

Aspek ke empat adalah Commitment. Orang takkan mengikuti para pemimpin yang tidak memiliki komitmen. ${ }^{19}$ Jones mengatakan bahwa seorang pemimpin yang tidak mempunyai komitmen yang kuat pada cita-citanya tidak akan mampu menggugah komitmen dari orang-orang lain. Contoh pemimpin yang memegang teguh komitmen pada cita-citanya adalah Yesus, Ia bersedia berjalan sendirian, dan memang melakukannya ketika tiba saat untuk membayar harga komitmennya. ${ }^{20}$ Kepemimpinan rohani memunyai komitmen langsung kepada Yesus sebagai Penebus dan Tuhan. Sekali kita meletakkan komitmen ini maka segala perilaku Kepemimpinan kita harus berpadanan dengan apa yang digariskan Kristus sendiri. Memang seorang pemimpin dalam mengekspresikan kepemimpinannya akan berbeda satu dengan yang lain dan memang setiap manusia adalah unik, tetapi yang terpenting tetap adanya alat kontrol yang mengendalikan dan menjaga agar komitmen tidak dilanggar.

Komitmen adalah bagian dari integritas. Integritas berasal dari bahasa Latin "integrare" yang artinya "menjadi utuh" dan diadopsi ke dalam bahasa Inggris sebagai "integrity". Jadi, integritas adalah tentang sesuatu kesatuan yang utuh. Pemimpin dengan integritas adalah seorang yang mempunyai kepribadian utuh dalam kata dan perbuatan. Komitmen adalah sebuah jangkar yang membuat seorang pemimpin tidak mudah terseret arus di saat gelombang besar menerpa. Komitmen adalah sebuah janji yang diucapkan pada diri sendiri.

Aspek ke empat ini dalam praktiknya akan saling kontrol dengan Conviction. Suatu komitmen dilanggar apabila terjadi perubahan visi dalam hidupnya, maka ini harus dikontrol lagi dengan refleksi dirinya kepada Tuhan, dan ia harus mengkaji ulang, menata dan meluruskan visinya kembali.

Demikianlah ke empat aspek tersebut di atas adalah vital bagi kepemimpinan seorang Pemimpin transformatif kristiani. Ke empatnya saling terkait dan mendukung, dan tak dapat dipisahkan dengan Identity, Integrity dan Intimacy dalam kehidupan seorang pemimpin yang telah dibahas di halaman sebelumnya.

\footnotetext{
${ }^{19}$ Barna, Leaders..., 31-32

${ }^{20}$ Laurie Beth Jones, Yesus CEO, (Jakarta: Penerbit Mitra Utama, 1997), 48.
} 
Transformasi adalah proses pembentukan dan perubahan pola pikir, sikap dan perilaku untuk membangun karakter manusia baru yang memiliki nilai lebih bagi organisasi. ${ }^{21}$

Konsep perubahan itu menyangkut perubahan bentuk dari luar dan perubahan karakter. Untuk mengubah sebuah gereja, pendeta harus menghadapi tiga kebenaran, yaitu: (1) dia telah berubah di waktu yang lampau, (2) dia harus bersedia berubah seperti para pengikutnya diubah, (3) dia harus bersedia menghadapi problemproblem dalam memimpin orang melalui perubahan. ${ }^{22}$ Hayford berpendapat bahwa dengan memiliki karakter rohani, dijamin ada buah-buah sejati, pengaruh yang abadi dan kepemimpinannya yang bertahan lama. ${ }^{23}$ Transformasi atau perubahanperubahan itu merupakan proses pembentukan pola pikir, sikap dan perilaku untuk membangun karakter manusia baru yang memiliki nilai lebih bagi dirinya, keluarga, organisasi tempat ia mengabdi, bagi bangsa dan Negara, dan khususnya bagi Tuhan. $^{24}$ Karena untuk itulah manusia diciptakan, yaitu untuk mengasihi dan melayani Tuhan, sesama dan lingkungan hidupnya. Proses transformasi dalam diri kita tersebut dapat membawa kita pada sebuah kehidupan yang luar biasa, baik dalam bidang finansial, karier, usaha, hubungan dengan sesama, maupun kesehatan secara fisik, emosi, mental dan spiritual.

Transformasi hakikat hidup tersebut dimulai dari hati. Alkitab mengatakan dari hati terpancar kehidupan, sebab itu hati harus dipelihara baik-baik (Ams. 4:23). Tranformasi berarti menjadi ciptaan baru. Ciptaan baru dalam diri kita dimungkinkan karena karya penebusan Yesus. Alkitab mengatakan "Jadi siapa yang ada di dalam Kristus, ia adalah ciptaan baru: yang lama sudah berlalu, sesungguhnya yang baru sudah datang (2 Kor. 5:17)."

Wofford menuliskan teori tentang kepemimpinan transformasi yang menjadikan Yesus adalah model sempurna dari model kepemimpinan ini. Berkaitan penggembalaan dan pertumbuhan gereja, berikut ini adalah prinsip-prinsip dalam kepemimpinan transformasi, yang bisa kita implementasikan. ${ }^{25} 2627$

21 Aribowo Prijosaksono \& Marlan Mardianto, The Power of Transformation, (Jakarta: Gramedia, 2005), xii

${ }^{22}$ Di dalam Barna, Leaders..., 235.

${ }^{23}$ Di dalam Barna, Leaders..., 75.

${ }^{24}$ Aribowo Prijosaksono \& Marlan Mardianto, The Power ..., xi.

25 Berdasarkan penelitian Bernard M. Bass, Leadership and Performance Beyond Expectations, (New York: The Free Press, 1985) dan James MacGregor Burns, Leadership, (New York: Harper \& Row, 1978).

26 Dengan menyediakan konsep dan standard pengukuran yang rinci dengan melakukan penelitian yang ekstensif tentang organisasi kepemimpinan, Bass telah memberikan kontribusi perluasan pemahaman kepada pembacanya tentang kepemimpinan yang transformasional. Penelitiannya dengan konsisten menunjukkan kepemimpinan transformasi sangat efektif di dalam berbagai organisasi yang sangat luas. Disamping diadakan sejumlah penelitian sekular, beberapa tesis dan disertasi telah meneliti penggunaan kepemimpinan transformasi dalam konteks Kristen. Peter Borgdoff, "Transformational Leadership in the Church" (diskusi doktoral, Western Theological Seminary, 1990). Russel Duke, "Communicating Transformational Leadership in Life of The Christian Laity" (diskusi doktoral, The Union Institute, 1993). Jennifer T. Webb, "Transformational Leadership among Religious Leaders" (thesis master, DePaul University, 1996).

${ }^{27}$ Jeffrey Fulks, "Transformational Leadership and its Relationship to Success in Developing New Churches" (diskusi doktoral, The University of Texas di Arlington, 1994). Dia adalah mantan 
Pertama, pemimpin transformatif mempunyai nilai-nilai yang diperjuangkan. Pemimpin transformasi yang mengubahkan harus mendasarkan nilai-nilai mereka pada Kitab Suci, nilai-nilai yang diajarkan Yesus adalah: Kebenaran (Yoh. 8:32), Firman Allah (Luk. 6:46-49), Kasih (Mark. 12:29-31), Iman (Mark. 11:22-24), Penginjilan (Luk. 10:16), Saksi (Mat. 10:32), Ibadah (Mark. 11:17), Pelayanan (Mat. 20:25-28), Doa (Luk. 11:2-4,13 ; 18:4-8), Pemberian (Mark. 12:43-44; Luk. 21:2-4), Pertumbuhan (Yoh. 17:19-26), Kesatuan (Yoh. 17:11). ${ }^{28}$

Kedua, pemimpin transformatif adalah pemimpin yang visioner. Visi harus datang dari dalam, kita tak bisa membeli atau memintanya dari orang lain. Kreativitas dan hasrat seseorang dapat menjadi sumber visinya. Visi timbul dari pengalaman. Visi tumbuh dari masa lalu sang pemimpin serta pengaruh orang-orang di sekelilingnya dalam sejarah kehidupannya. Visi memenuhi kebutuhan orang lain. Visi yang sejati memiliki jangkauan yang luas, tak hanya melibatkan orang lain namun juga memberikan nilai tambah bagi orang lain. Visi yang besar melayani orang-orang lain. Visi membantu anda mengumpulkan sumber-sumber daya. Semakin besar, menarik, dan menantang sebuah visi, maka akan menarik semakin banyak sumber-sumber daya. Setelah visi dapat ditangkap, keberhasilan seorang gembala sidang transformatif ditentukan oleh seberapa jauh ia melakukan persiapan. Saat seseorang mempersiapkan dirinya dengan lebih baik, maka ia akan lebih percaya diri dan mendapat kepercayaan dari orang-orang lain. Saat gembala sidang transformatif telah menentukan visi bagi gerejanya, gembala sidang harus membuat perencanaan dan mengkoordinir sumber daya manusianya untuk bergerak mencapai visinya itu. ${ }^{29}$

Pemimpin transformatif adalah pribadi kreatif dan inovatif. Kreativitas adalah kemampuan untuk melihat solusi dan memperbaiki masalah. ${ }^{30}$ Yesus menentang status quo. Para pemimpin transformatif adalah agen perubahan. Mereka tidak puas dengan status quo, mereka harus berusaha keluar dari tradisi dan kebiasaan yang sudah ada untuk membawa jemaat dan meraih panggilan Allah yang tertinggi. Pemimpin transformatif adalah pemimpin yang karismatik. Pemimpin yang karismatik memberi keteladanan pada para pengikutnya dalam pengorbanan diri, hidup dalam kebenaran alkitabiah dan menjadi model dari pribadi Allah. Pemimpin transformatif adalah gembala yang baik. Para pemimpin transformatif adalah pemelihara domba, mereka peka terhadap kebutuhan para pengikutnya. Mereka merawat domba-domba yang lapar dan haus dengan penuh kasih, menyingkirkan kerusakan dan gangguan, melindungi dan mempertahankan mereka, mengobati luka dan kepedihan mereka, dan mendisiplin mereka. (Mat. 20:25-28; Maark. 9:35-37; Mark. 10:35-44; Luk. 22:24-30 ; Yoh. 10:11-18; 21:15-19).

Pemimpin transformatif adalah seorang katalisator. Yesus menyentuh hati dan pikiran (Mat. 5:1-12). Esensi kepemimpinan Kristen yang transformatif adalah

\footnotetext{
mahasiswa Wofford di University Texas di Arlington, meneliti kepemimpinan transformasi para pendiri gereja di gereja-gereja Sidang Jemaat Allah.

${ }_{28}$ Jerry C. Wofford, Kepemimpinan Kristen Yang Mengubahkan, (Yogyakarta: Andi, 2008), 5

${ }^{29}$ John Maxwell, The Indispensable 21 Qualities of a Leader, (Batam: Interaksara, t.t), 209211

${ }^{30}$ Jerry C. Wofford, Kepemimpinan Kristen ..., 5.
} 
pada pengaruhnya terhadap pikiran dan perilaku para pengikut mereka. Kepemimpinan tersebut merangsang para pengikut untuk keluar dari status quo, mencari perspektif baru ketika menyelesaikan masalah-masalah lama dan mengamati masalah dari berbagai sudut yang berbeda. Para pemimpin transformatif tidak berpikir untuk pengikutnya; mereka berpikir bersama mereka. Yesus adalah pemimpin yang revolusioner, yang datang untuk memperbaharui kehidupan manusia dan mengubah pemahaman mereka tentang Allah. Yesus mengajarkan murid-muridNya dengan menggerakkan pikiran dan hati (Mat. 5:1-7; 13:1-52). ${ }^{31}$ Peranan gembala sidang transformatif adalah sebagai katalisator yang kreatif, inovatif dan fleksibel bagi gerejanya. Peranan gembala sidang yang transformatif adalah sebagai perancang atau kreator bagi gerejanya. Sebagai kreator dari sebuah proyek dia harus bisa melihat jauh ke depan untuk mendesain (merencanakan) segala sesuatunya demi keberhasilan untuk mencapai tujuan gerejanya. Gembala sidang yang transformatif adalah agen perubahan. Ia membuat tindakan nyata dan membawa perubahan positif bagi kemajuan jemaat dan gerejanya. Ia terbuka dan fleksibel terhadap perubahan-perubahan dalam penatalayanan gerejanya.

Pemimpin transformatif adalah seorang pemimpin yang melayani. Yesus adalah Raja Segala Raja sebagai pemimpin yang melayani. Yesus adalah model sempurna dari kepemimpinan yang melayani. Yesus berkata bahwa Ia datang bukan untuk dilayani tapi untuk melayani dan memberikan kehidupan-Nya. Para pemimpin transformatif mengubahkan dan membangun orang lain melalui pelayanan mereka yang rendah hati. Mereka mengorbankan diri mereka sendiri untuk meyakinkan bahwa kebutuhan sejati orang lain dipenuhi. Yesus mengajarkan pada para muridNya tentang kepemimpinan yang melayani (Mat. 20:25-28; Mark. 9:35-37; 10:3544; Luk. 17:1-10; 22:24-30). ${ }^{32}$ Seorang gembala sidang transformatif adalah seorang pemimpin yang karismatik dan berintegritas, yang memberikan hidupnya bagi kemajuan dan pertumbuhan jemaat dan gerejanya. Peranan gembala sidang transformatif adalah sebagai seorang komunikator dan katalisator yang baik bagi jemaat dan gerejanya. Kemampuan komunikasinya yang baik dan pribadinya yang karismatik, membuat orang lain mudah mengikutinya.

Sebagai akhir pada pembahasan Kepemimpinan Transformasi ini, penulis merangkumkan bahwa inti dari kepemimpinan transformasi kristiani adalah sebagai berikut: seorang pemimpin transformatif dapat mengubah hidup orang lain dengan keberadaan dirinya. Seorang pemimpin transformatif mengubahkan hidup orang lain melalui diri dan kehidupannya. Eksistensi dirinya memberikan perubahan bagi orang lain dan lingkungan di mana dia berada. Di sini dibutuhkan kemampuan berkomunikasi dari sang pemimpin kepada orang di luar dirinya. Komunikasi adalah alat satu-satunya yang menghubungkan sang pemimpin dan dunia di luar dirinya. Komunikasi dimulai dari dalam dirinya, dibawa ke luar dirinya. Komunikasi berakar dan bertumbuh dari dalam diri pemimpin untuk di bagikan ke dunia di luar dirinya. Ini bicara soal character, conviction dan commitment yang berakar pada Tuhan yang

${ }^{31}$ Colin Turner, Lead to Succeed. Menuju Sukses, (Jakarta: PT Elex Media Komputindo, 2003), 7

${ }^{32}$ Colin Turner, Lead to Succeed. Menuju ....., 7 
didukung oleh competency dari sang pemimpin tumbuh menjadi Identity yang kuat tentang siapa dirinya di mata Tuhan, menjadi suatu kekuatan yang menjadikan dirinya memiliki Integrity, dan ia tetap menjaga Intimacy secara vertikal dan horizontal dengan Tuhan dan sesama manusia.

Kepemimpinan berjalan seiring dengan komunikasi dan transformasi. Transformasi hanya dapat dicapai dengan komunikasi yang efektif oleh seorang pemimpin. Komunikasi yang efektif harus dapat menyentuh sampai jauh ke dalam lubuk hati seseorang. Komunikasi adalah suatu hal yang praktis, karenanya harus ada bukti. Bukti inilah yang membuat orang lain tersentuh dan sadar akan betapa berharganya nilai-nilai yang dikomunikasikan sang komunikator.

Komunikasi paling efektif dari seorang pemimpin kristiani adalah keberadaan dirinya sendiri, yaitu bukti kehidupannya. Komunikasi tidak selalu verbal, komunikasi tercermin lewat tindakan seseorang, yaitu hidup sang pemimpin. Komunikasi bicara tentang kehidupan. Kehidupan seorang hamba Tuhan yang mencerminkan adanya karakter Kristus di dalam dirinya adalah bukti adanya awal dari sumber komunikasi itu sendiri. Komunikasi berasal dari Tuhan sendiri. Seorang pemimpin yang menyadari kasih dan anugerah Tuhan adalah seorang komunikator yang baik. Hidupnya mengkomunikasikan kasih Tuhan. Semua pemimpin kristiani adalah komunikator. Semua hamba Tuhan adalah komunikator. Semua orang Kristen adalah komunikator. Kita semua adalah komunikator-komunikator yang menyampaikan kasih Tuhan pada dunia. Inti komunikasi adalah tentang Tuhan, bukan kita, kita hanya media komunikasi (komunikator) yang dipakai Tuhan untuk dunia.

Komunikator-komunikator kristiani adalah saksi-saksi Kristus. Semua pemimpin transformatif adalah komunikator kristiani. Identitas kita adalah terang dunia dan garam dunia. Tugas kita adalah melaksanakan amanat agung Tuhan (Mat. 28:19-20). Perwujudan karya kita di dunia salah satunya adalah berkarya di gereja. Karena itu, dalam penulisan artikel ini penulis membatasi pada peran pemimpin kristiani sebagai Gembala Sidang, karenanya tujuan yang ingin dicapai adalah pertumbuhan gereja dalam hal kuantitas dan kualitas. Berikut adalah pembahasan tentang pertumbuhan gereja yang ujung-ujungnya juga tidak lepas dari ketrampilan mengkomunikasikan pesan dari sang pemimpin kepada orang yang dipimpinnya. 


\section{BAB III}

\section{PERTUMBUHAN GEREJA}

Gereja Yesus Kristus sebagai sebuah organisme hidup mengalami pertumbuhan. ${ }^{33}$ Peters mendasarkan pertumbuhan gereja pada Diri Yesus sendiri (Mat. 16:18) sebagai batu penjuru (Yes. 28:16; bdk I Kor. 3:11; Ef. 2:20; I Pet. 2:68). ${ }^{34}$ Ia merekrut murid-murid-Nya untuk menjadi kawan kerja-Nya yaitu Rasulrasul, Nabi-nabi, Pekabar-pekabar Injil, Gembala-gembala, dan Pengajar-pengajar. Di zaman sekarang Tuhan memanggil dan memakai semua orang Kristen untuk menjadi Gereja-Nya.

Pelopor Gerakan Pertumbuhan Gereja, Gravan berpendapat bahwa "Tuhan menghendaki agar domba-domba-Nya yang hilang diketemukan dan dibawa kembali ke kandangnya". ${ }^{35}$ Asumsi teologisnya dijadikan pegangan oleh setiap pendukung gerakan pertumbuhan gereja. Jenson dan Stevens mengatakan bahwa pertumbuhan Gereja adalah kenaikan yang seimbang dalam kuantitas dan kualitas serta kompleksitas organisasi sebuah gereja lokal. ${ }^{36}$ Sedangkan Warren berpendapat bahwa pertumbuhan gereja yang sejati terdiri dari lima segi. Pertumbuhan gereja meliputi segi kuantitas dan kualitas jemaat serta ditunjang oleh kepemimpinan Gembala Sidang gereja setempat dari segi penataan organisasi gerejanya, yang meliputi persekutuan, pemuridan, ibadah, pelayanan dan penginjilan. Dasar pertumbuhan kuantitas ialah jadikanlah semua bangsa murid-Ku dan baptislah mereka dalam nama Bapa dan Anak dan Roh Kudus, dan ajarlah mereka melakukan segala sesuatu yang telah Kuperintahkan kepadamu (Mat. 28:19-20). ${ }^{37}$

Pertumbuhan gereja merupakan akibat wajar dari gereja yang sehat. Kesehatan sebuah gereja sangat penting. Gereja yang sehat hanya dapat terjadi jika khotbah kita alkitabiah dan misi kita seimbang. Allah menginginkan kesehatan roh, jiwa, dan tubuh kita seimbang (1 Tes. 5:23). Menurut Jenson dan Stevens, iklim dalam suatu gereja yang sehat dan bertumbuh adalah kombinasi faktor-faktor yang menentukan bagaimana seseorang merasakannya sebagai bagian gereja. Tiga faktor yang menunjang iklim suatu gereja yang pada dasarnya berkenaan dengan soal iman, kasih dan relasi.

Gereja bertumbuh oleh kuasa Allah melalui usaha manusia yang terampil. Sementara kita menunggu Allah bekerja untuk kita, Allah sedang menunggu kita untuk bekerja melalui kita. Pepatah mengatakan Ora et Labora, kita berdoa dan juga bertindak dengan penuh tanggungjawab. Kualitas menunjuk pada jenis muridmurid yang dihasilkan oleh suatu gereja. Kuantitas menunjuk pada jumlah muridmurid yang dihasilkan oleh suatu gereja. Di dalam gereja, selama masih ada orang-

${ }^{33}$ Ron Jenson \& Jim Stevens, Dinamika Pertumbuhan Gereja, (Malang: Gandum Mas, t.t), 8

${ }^{34}$ George W. Peters, Teologi Pertumbuhan Gereja, (Malang: Gandum Mas, 2002), 76

${ }^{35}$ Di dalam C. Peter Wagner, Strategi Perkembangan Gereja, (Malang: Gandum Mas, 1996),

${ }^{36}$ Jenson\&Stevens, Dinamika..., 8

${ }^{37}$ Rick Warren, Pertumbuhan Gereja Masa Kini, (Malang: Gandum Mas, 2003), 54-55. 
orang yang terhilang dalam dunia ini, kita tetap harus peduli pada kuantitas dan juga kualitas. Kualitas menghasilkan kuantitas, dan kuantitas menciptakan kualitas dalam beberapa segi kehidupan gereja. Hal ini dimungkinkan apabila pemimpin di gereja itu pun memiliki jasmani dan rohani yang sehat pula. ${ }^{38}$

Dinamika paling utama yang mendasari pertumbuhan gereja adalah kuasa Roh Kudus. Roh Kudus merupakan dasar pertumbuhan semua gereja. ${ }^{39}$ Paulus mengatakan: Aku menanam, Apolos menyiram, tetapi Allah yang memberi pertumbuhan. (1Kor. 3:6). Schwarz menemukan sebuah konsep pertumbuhan gereja yang suprabudaya dan berpendapat bahwa karakteristik kualitas yang esensial atau mutlak dalam pertumbuhan gereja adalah kepemimpinan yang melakukan pemberdayaan (pemuridan) (Ef. 4:12), pelayanan yang berorientasi kepada karunia (1 Pe.t 4:10), ibadah yang membangkitkan inspirasi (1 Tes. 5:1619), kelompok kecil (persekutuan) yang menjawab kebutuhan secara menyeluruh (Kis. 2:42-47) dan penginjilan yang berorientasi kepada kebutuhan (1 Kor. 9:2022). ${ }^{40}$

Pertumbuhan sebuah gereja membutuhkan pemuridan yang sungguh-sungguh (Ef. 4:12). Menurut Scheunemann telah membuktikan bahwa gembala yang mendapatkan skor paling tinggi dalam pemberdayaan bukanlah pendeta yang terkenal, tetapi yang serius dalam melatih dan membina (memuridkan) jemaatnya. ${ }^{41}$ Pertumbuhan gereja juga membutuhkan pelayanan yang berorientasi kepada karunia (1 Pet. 4:10). Setiap orang percaya diciptakan untuk melayani (Ef. 2:10), diselamatkan untuk melayani (II Tim. 1:9), terpanggil ke dalam pelayanan (I Pet. 2: 9-10), diberi karunia untuk melayani (I Pet. 4:10), diberi kuasa untuk melayani (Mat. 28:18-20), diperintahkan untuk melayani (Mat. 20:26-28), diperlengkapi untuk melayani (Ef. 4:11-12), dibutuhkan untuk melayani (I Kor. 12:27).

Pertumbuhan gereja membutuhkan ibadah yang membangkitkan inspirasi (1 Tes. 5:16-19). Menurut Rainer Scheunemann penelitian membuktikan bahwa faktor yang menentukan pertumbuhan gereja adalah "adanya ibadah yang merupakan pengalaman yang membangkitkan inspirasi bagi mereka yang menghadirinya" Selain itu, pertumbuhan gereja membutuhkan kelompok kecil (persekutuan) yang menjawab kebutuhan secara menyeluruh (Kis. 2:42-47). Keberadaan sebuah kelompok kecil (persekutuan) bagi gereja, adalah langkah yang efektif untuk mengangkat pertumbuhan gereja, sebab dalam komunitas ini setiap pribadi dapat menjalin keakraban satu sama lain, bertumbuh bersama-sama.

Pertumbuhan jemaat tidak mungkin terjadi tanpa penginjilan. Penginjilan merupakan nafas gereja. Sesuai dengan Matius 28:19-20 dan Lukas 14: 28-33, Scheunemann mengatakan ada lima hal yang dapat disimpulkan dalam proses penginjilan: (1) Kepekaan terhadap situasi kebutuhan, krisis dan pergumulan para

${ }^{38}$ Scazzero \& Bird, Gereja Yang Sehat ...., 10.

${ }^{39}$ C. Peter Wagner, Pertumbuhan Gereja dan Peranan Roh Kudus, (Malang: Gandum Mas, 1996), 27

${ }^{40}$ Christian Schwarz dkk, Pertumbuhan Gereja yang Alamiah, (Jakarta: Metanoia, 1999) di dalam Rainer Scheunemann, Menuju Jemaat yang Misioner, (Sekolah Alkitab Malam Gereja Kristen Injili di Tanah Papua, 2003), 94-116

${ }^{41}$ Rainer Scheunemann, Menuju Jemaat Yang Misioner (Sekolah Alkitab Malam Gereja Kristen Injili di Tanah Papua, 2003), 96 
pendengar, (2) Pewartaan Injil yang jelas dan mudah untuk dimengerti tanpa mengurangi isi Injil itu sendiri, (3) Pemahaman para pendengar akan berita Injil perlu diteliti, (4) Pengambilan keputusan untuk menerima Injil dengan memakai rasio/akal, kehendak serta perasaan - setiap penginjilan yang bersifat manipulatif harus ditolak, (5) pemuridan yaitu pengajaran mereka yang telah menerima Injil dalam dasar-dasar iman kristiani dan penerapannya dalam kehidupan sehari-hari. ${ }^{42}$

Kelima karakteristik kualitas yang esensial atau mutlak dalam pertumbuhan gereja yang suprabudaya adalah kepemimpinan yang melakukan pemberdayaan (pemuridan), pelayanan yang berorientasi kepada karunia, ibadah yang membangkitkan inspirasi, kelompok kecil (persekutuan) yang menjawab kebutuhan secara menyeluruh dan penginjilan yang berorientasi kepada kebutuhan. Kelima hal ini tak terlepas dari kelihaian berkomunikasi pemimpinnya. Pemimpin adalah tokoh kunci, seorang komunikator yang dengan dirinya, dengan bukti kehidupannya sebagai agen transformator handal yang menyampaikan nilai-nilai Alkitab untuk mengubahkan hidup orang lain.

\section{SIMPULAN}

Gereja yang sehat adalah gereja yang Gembala Sidangnya (pemimpinnya) sehat jasmani, rohani dan spiritualitasnya. Gembala sidang sebagai seorang pemimpin rohani yang dipanggil Tuhan memiliki kepemimpinan transformasi yang dijiwai semangat kristiani; yang menentukan visi yang dari Allah bagi jemaat dan pertumbuhan gerejanya, yang mengubah pola pikir, sikap, perilaku dan karakter seseorang supaya sesuai dengan karakter Kristus yang bertujuan untuk memiliki nilai lebih bagi dirinya, keluarganya, gerejanya, pelayanannya, organisasinya, pekerjaannya, masyarakatnya dan bangsanya dan yang menentukan pertumbuhan gereja dari segi kuantitas dan kualitas serta kompleksitas organisasi gereja.

Peranan gembala sidang transformatif adalah sebagai pemimpin katalisator yang berjiwa hamba yang karismatik dan berintegritas penuh kreativitas dan inovasi yang akan membawa perubahan dan pertumbuhan bagi gerejanya. Peranan gembala sidang transformatif adalah sebagai pelayan bagi jemaat dan gerejanya, ia mempraktikkan kepemimpinan hamba (servant leadership) dari Yesus Kristus. Peranan gembala sidang transformatif adalah sebagai komunikator dan koordinator yang baik; sebagai pemimpin yang memberdayakan jemaat di gerejanya. Gembala sidang yang transformatif adalah seorang mentor dan organisator (manajer) yang baik. Ia melatih, memberdayakan, mengkoordinir dan melibatkan jemaatnya dalam pelayanan dengan bijaksana. Peranan gembala sidang transformatif adalah sebagai pemimpin yang fleksibel, seorang komunikator dan katalisator yang handal. Kemampuan komunikasinya yang baik dan pribadinya yang karismatik, membuat orang lain mudah mengikutinya. Ia bisa bergaul, menjalin hubungan dan berkomunikasi dengan siapa saja.

${ }^{42}$ Scheunemann, Menuju Jemaat..., 113 
Seorang Gembala Sidang yang transformatif adalah seorang komunikator yang memiliki Identity, Integrity, Intimacy yang jelas tercermin di dalam Character, Competency, Conviction dan Commitment dalam kehidupan pelayanannya.

Mengingat hasil kajian terhadap peranan kepemimpinan transformasi gembala sidang berpengaruh besar dan positif terhadap pertumbuhan gereja di masa kini, maka sebagai masukan, dapat disarankan kepada para gembala sidang untuk meningkatkan kepemimpinannya dengan mengimplementasikan prinsip kepemimpinan transformasi dalam perannya sebagai gembala sidang di gerejanya masing-masing. Kiranya kajian ini dapat memberikan wacana baru, membuka paradigma dan memberikan harapan baru terhadap para gembala sidang di dalam melaksanakan tugas penggembalaan yang telah dipercayakan Allah kepada mereka.

\section{DAFTAR PUSTAKA}

Blackaby, Henry \& Richard

t.t Kepemimpinan Rohani (Spiritual Leadership). Batam: Gospel Press

Barna, George

2002 Leaders on Leadership. Malang: Gandum Mas

Barna, George

2005 The Habits of Highly Effective Churches. Malang: Gandum Mas

Bowling, John C.

2001 Kepemimpinan Penuh Kasih Karunia. Jakarta: Metanoia

Clinton, Richard \& Paul Leavenworth

2004 Memulai dengan Baik. Jakarta: Metanoia

Damazio, Frans

1993 Kunci-kunci Efektif bagi Kepemimpinan yang Sukses. Jakarta: Harvest Publication House

Handojo, Surjo

2010 Personal Leadership

Jenson, Ron \&Jim Stevens

t.t Dinamika Pertumbuhan Gereja. Malang: Gandum Mas

Kartono, Kartini

1980 Teori Kepribadia. Bandung: Penerbit Alumni 
Munroe, Myles

2006 The Spirit of Leadership. Jakarta: Penerbit Immanuel

Mimery, Nehemia

t.t Rahasia Tentang Penggembalaan Jemaat. Bandung: Mimery Press

Maxwell, John

t.t The Indispensable 21 Qualities of a Leader. Bandung: Interaksara

Peters, George W.

2002 Teologi Pertumbuhan Gereja. Malang: Gandum Mas

Prijosaksono, Aribowo \& Marlan Mardianto

2005 The Power of Transformation. Jakarta: Gramedia

Scazzero, Peter \&Warren Bird

2005 Gereja yang Sehat Secara Emosional. Batam: Gospell Press

Scheunemann, Rainer

2003 Menuju Jemaat yang Misioner. Sekolah Alkitab Malam Gereja Kristen Injili di Tanah Papua

Sendjaya

2004 Kepemimpinan Kristen. Yogyakarta: Penerbit Kairos

Storm, M.Bons

2000 Apakah Penggembalaan Itu? Jakarta: PT BPK Gunung Mulia

Sudomo

2005 Ciri Utama Kepemimpinan Sejati. Yogyakarta: Penerbit Andi

Suria, Isak

2007 Pembentukan Karakter Pemimpin Kristen (Spirituality Formation). Malang: GTI Bukit Zaitun

Teddywono, Innawati

2010 Tesis: Pengaruh Kepemimpinan Kristen Berbasis Kewirausahaan dan Pemberdayaan Jemaat terhadap Pertumbuhan Gereja. Studi Kasus di Gereja Pantekosta Pusat Surabaya Elim Malang. Malang: STT Salem 
Tirtamihardja, Samuel H.

2003 Pemimpin adalah Pemimpi. Editor: Hendra Kasenda, t.p.

Tomatala, Yakob

1997 Kepemimpinan yang Dinamis. Malang: Gandum Mas

Turner, Colin

2003 Lead to Succeed. Menuju Sukses. Jakarta: PT Elex Media Komputindo

Wagner, C. Peter

1996 Strategi Perkembangan Gereja. Malang: Gandum Mas

Agner, C. Peter

1996 Pertumbuhan Gereja dan Peranan Roh Kudus. Malang: Gandum Mas

Warren, Rick

2003 Pertumbuhan Gereja Masa Kini. Malang: Gandum Mas

White, John

1994 Kepemimpinan yang Handal. Bandung: Kalam Hidup

Wiersbe, Warren

1990 Setia di dalam Kristus. Bandung: Kalam Hidup

Wilkinson, Bruce $\mathrm{H}$.

2001 Personal Holiness of Temptation. Surabaya: Yakin

Willard, Dallas

2006 Renovation of the Heart. Malang: SAAT

Wofford, Jerry C.

2008 Kepemimpinan Kristen yang Mengubahkan. Yogyakarta: Andi

Yudho, Bambang

2006 How to Become a Christian Leader, Prinsip-prinsip

Kepemimpinan Kristen. Yogyakarta: Penerbit Andi

Yukl, Gary

2005 Kepemimpinan dalam Organisasi. Jakarta: Gramedia 